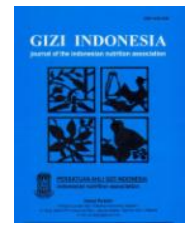

Journal of the Indonesian Nutrition Association http://ejournal.persagi.org/go/ p-ISSN: 0436-0265 e-ISSN: 2528-5874

\title{
ASUPAN SENG YANG RENDAH SEBAGAI FAKTOR RISIKO KEPARAHAN PNEUMONIA PADA ANAK USIA 12-59 BULAN
}

\section{Low Zinc Intake as a Risk Factor of Severe Pneumonia among Children Aged 12-59 Months}

\author{
Meiry Nasution ${ }^{1}$, Mohammad Hakimi ${ }^{1}$, T. Ninuk Sri Hartini² \\ ${ }^{1}$ Fakultas Kedokteran, Universitas Gadjah Mada, Yogyakarta \\ 2Jurusan Gizi, Poltekkes Kemenkes, Yogyakarta \\ E-mail:ninuk_sh@yahoo.co.uk
}

\begin{abstract}
Period prevalence of infant pneumonia in Indonesia is 18.5 per mile. The high mortality rate due to pneumonia of 62 percent was found in 10 countries and 5 countries was located in Asia. Zinc is one of micronutrients which is reported to prevent pneumonia as an acute phase response to infection and help to boost the body immune response. The objective of the study was to determine the impact of zinc intake as risk factor of severe pneumonia in children. A case control study was conducted among children aged 12-59 months in 2 hospitals and 6 health centres, Yogyakarta city. Thirty four children were categorized as having severe pneumonia (cases) and 102 children were categorized as having pneumonia (control). All sample's mothers completed a semi-quantitative food frequency questionnaire during March-April 2014. Data analysis was performed using Mantel-Haenszel test and conditional logistic regression, $\alpha=$ 0,05 . Results of the study showed that there were $\mathbf{4 1 . 2}$ percent cases and 56.9 percent control were exclusively breast-fed. The proportion of cases who had inadequate zink intake was higher than control group. There was no difference between inadequate zinc intake and the severe pneumonia (OR 1,08 and $95 \% \mathrm{Cl} 0,5-2,3)$. There was a statistically significant correlation between low-zinc intake and severe pneumonia if second disease exist (OR 3,8 and $95 \% \mathrm{Cl} 1,4-10,8)$. As an conclusion, Inadequate zinc intake affected severe pneumonia when the secondary diseases exist in children with pneumonia.
\end{abstract}

Keywords: zinc intakes, pneumonia, risk factors, children aged 12-59 months

\section{ABSTRAK}

Period prevalence pneumonia balita di Indonesia adalah 18,5 per mil. Angka kematian yang tinggi akibat pneumonia sebesar 62 persen terdapat di 10 negara dan 5 negara di antaranya merupakan negara di Asia. Defisiensi seng menyebabkan penurunan kekebalan sel sehingga meningkatkan kerentanan terhadap penyakit pneumonia. Tujuan penelitian ini menganalisis asupan seng yang kurang sebagai faktor risiko keparahan pneumonia pada anak. Desain penelitian case control pada 136 anak usia 12-59 bulan yang diperoleh dari 2 RS dan 6 puskesmas di Kotamadya Yogyakarta. Sampel terdiri dari 34 anak menderita pneumoni berat (kasus) dan 102 anak menderita pneumonia sebagai kontrol. Ibu sampel melengkapi data asupan seng melalui frekuensi makan semi-kuantitatif pada bulan Maret-April 2014. Sejumlah 45 makanan dicantumkan pada kuesioner frekuensi makan. Analisis data dilakukan dengan uji Mantel-Haenszel dan regresi logistik bersyarat dengan $a=0,05$. Hasil penelitian menunjukkan bahwa sejumlah 41,2 persen kelompok kasus dan 56,9 persen kontrol mendapat air susu ibu (ASI) eksklusif. Proporsi kasus yang asupan sengnya kurang ternyata lebih tinggi dari kelompok kontrol. Tidak ada perbedaan antara asupan seng dan keparahan pneumonia (OR 1,08 dan $95 \% \mathrm{Cl} 0,5-2,3)$. Ada korelasi yang signifikan antara asupan seng yang kurang dan keparahan pneumonia jika disertai penyakit penyerta (OR 3,8 dan $95 \% \mathrm{Cl} 1,4-10,8)$. Kurangnya asupan seng berpengaruh terhadap terjadinya keparahan pneumonia jika disertai adanya penyakit penyerta pada anak-anak penderita pneumonia usia 12-59 bulan.

Kata kunci: asupan seng, pneumonia, faktor risiko, anak usia 12-59 bulan 


\section{PENDAHULUAN}

$P$ eriod prevalence pneumonia balita di ndonesia adalah 18,5 per mil. ${ }^{1}$ Berdasarkan data rumah sakit, Crude Fatality Rate (CFR) penderita pneumonia pada tahun 2007 sebesar 6,53 persen dan meningkat pada tahun 2008 sebesar 6,57 persen. $^{2}$

Pneumonia merupakan penyebab kematian paling banyak pada anak-anak di bawah lima 5 tahun dibandingkan dengan penyakit lain di beberapa negara di dunia. Angka kematian yang tinggi akibat pneumonia sebesar 62 persen terdapat di 10 negara dan 5 negara di antaranya adalah negara di Asia. ${ }^{3}$

Faktor imunologi pada anak yang menderita pneumonia dipengaruhi oleh asupan zat gizi mikro, salah satunya adalah seng. Defisiensi seng menyebabkan penurunan kekebalan sel sehingga meningkatkan kerentanan terhadap penyakit pneumonia. ${ }^{4}$ Zat gizi mikro, khususnya seng, memiliki peran penting pada imunitas. Pemberian seng mempunyai efek penyembuhan penyakit pneumonia dan pencegahan penyakit infeksi..$^{5-6}$

Berkembangnya penyakit pneumonia dipengaruhi oleh faktor pejamu (host) dan lingkungan pada anak-anak, terutama pada tahun pertama kehidupannya. . $^{7-8}$ Kematian akibat pneumonia berhubungan erat dengan faktor risiko yang dialami keluarga, seperti kemiskinan, kekurangan asupan pangan, dan keadaan lingkungan rumah yang mendukung berkembangnya pneumonia. ${ }^{9}$

Defisiensi seng kronis dapat menimbulkan penurunan berat badan anak, lalu menghambat pertumbuhan badannya, yang kelak menjadikannya pendek, serta pertahanan tubuhnya lemah terhadap penyakit infeksi. Defisiensi seng juga melemahkan respon imunitas pada anak-anak penderita pneumonia. ${ }^{9}$ Berbagai mekanisme kekurangan zat gizi meningkatkan kerentanan terhadap infeksi. Fungsi imun seluler terganggu pada individu sehingga episode penyakit infeksi menjadi lebih parah. ${ }^{10-11}$ Tujuan penelitian ini menganalisis pengaruh asupan seng sebagai faktor risiko terhadap keparahan penyakit pneumonia pada anak usia 12-59 bulan.

\section{METODE PENELITIAN}

Rancangan penelitian ini adalah case control. Penelitian ini dilakukan pada bulan
Maret-April 2014 di Rumah Sakit Bethesda, Rumah Sakit PKU Muhammadiyah, dan di wilayah kerja Puskesmas Umbulharjo I, Puskesmas Umbulharjo II, Puskesmas Gondokusuman II, Puskesmas Jetis, Puskesmas Tegalrejo dan Puskesmas Wirobrajan Kota Yogyakarta, Provinsi Daerah Istimewa Yogyakarta.

Diagnosis tingkat keparahan pneumonia, berdasarkan diagnosis dokter, diperoleh dari rumah sakit dan puskesmas di wilayah penelitian. Besar sampel minimum dalam penelitian ini adalah 34 dengan asumsi bahwa proporsi defisiensi seng pada pneumonia berat 0,54 dan pneumonia 0,32 dengan OR perkiraan $2,5, a=0,05$ dan power of the test 80 persen. Perbandingan kelompok kasus dan kontrol adalah 1:3. Total sampel 136 anak usia 12-59 bulan yang terdiri dari 34 kasus yang menderita pneumonia berat dan 102 kontrol yang menderita pneumonia. Pengambilan sampel kasus pada penelitian ini menggunakan metode konsekutif sampling (concecutive sampling) dan pengambilan sampel kontrol disesuaikan dengan jenis kelamin dan teknik simple random sampling. Orang tua sampel penelitian (kasus dan kontrol) bersedia anaknya menjadi sampel penelitian dan menandatangani informed consent. Anak yang sedang menderita gizi buruk dan anak yang mendapatkan suplementasi seng secara berkala tidak diikutsertakan pada penelitian ini.

Asupan seng diketahui melalui metode frekuensi makan semi kuantitatif (FM-SK). Sebanyak 45 makanan dicantumkan pada kuesioner FM SK. Formulir FM-SK telah diuji terlebih dahulu. Status gizi dikategorikan berdasarkan berat badan menurut umur (BB/U). Penyakit penyerta diketahui melalui rekam medis. Analisis data dilakukan dengan menggunakan uji Mantel-Haenszel dan multivariat dengan uji Conditional Logistic Regression, $a=0,05$. Penelitian telah disetujui oleh Tim Komite Etik Fakultas Kedokteran Universitas Gadjah Mada, Yogyakarta.

\section{HASIL}

Tabel 1 menunjukkan bahwa sebanyak 52,9 persen kelompok kasus berjenis kelamin laki-laki dan 35,3 persen kelompok kasus berusia 12-23 bulan. Sejumlah 30,4 persen kelompok kontrol berusia 36-47 bulan. Anak 
yang tidak mendapatkan air susu ibu (ASI) eksklusif pada kelompok kasus sebanyak 58,8 persen dan pada kelompok kontrol sebanyak 43,1 persen. Tingkat pendidikan ibu terbanyak pada kelompok kasus berpendidikan menengah sebesar 41,2 persen.

Pada kelompok kasus dan kontrol yang memiliki asupan seng kurang sebanyak 45,6 persen, terdiri dari 47,1 persen pada kelompok kasus dan 45,1 persen pada kelompok kontrol. Secara keseluruhan, sampel penelitian yang menderita gizi kurang sebanyak 10 anak $(7,4 \%)$, terdiri dari 3 anak $(8,8 \%)$ pada kelompok kasus dan 7 anak (6,9\%) pada kelompok kontrol. Secara lengkap dapat dilihat pada Tabel 2.

Tabel 1. Karakteristik Sampel Penelitian Berdasarkan Kelompok Kasus dan Kontrol

\begin{tabular}{|c|c|c|c|c|c|c|}
\hline \multirow{2}{*}{ Karakteristik Sampel } & \multicolumn{2}{|c|}{ Kasus } & \multicolumn{2}{|c|}{ Kontrol } & \multicolumn{2}{|c|}{ Total } \\
\hline & n (34) & $\%$ & $n(102)$ & $\%$ & $n(136)$ & $\%$ \\
\hline \multicolumn{7}{|l|}{ Jenis kelamin } \\
\hline a. Laki-laki & 18 & 52,9 & 54 & 52,9 & 72 & 52,9 \\
\hline b. Perempuan & 16 & 47,1 & 48 & 47,1 & 64 & 47,2 \\
\hline \multicolumn{7}{|l|}{ Umur (bulan) } \\
\hline a. $12-23$ & 12 & 35,3 & 24 & 23,5 & 36 & 26,2 \\
\hline b. $24-35$ & 9 & 26,5 & 30 & 29,4 & 39 & 28,7 \\
\hline C. $36-47$ & 8 & 23,5 & 31 & 30,4 & 39 & 28,7 \\
\hline d. $48-59$ & 5 & 14,7 & 17 & 16,7 & 22 & 16,4 \\
\hline \multicolumn{7}{|l|}{ Pemberian ASI eksklusif } \\
\hline a. Tidak ASI eksklusif & 20 & 58,8 & 44 & 43,1 & 64 & 47,1 \\
\hline b. ASI eksklusif & 14 & 41,2 & 58 & 56,9 & 72 & 52,9 \\
\hline \multicolumn{7}{|l|}{ Pendidikan ibu } \\
\hline a. Pendidikan dasar & 10 & 29,4 & 39 & 38,2 & 49 & 67,6 \\
\hline b. Pendidikan menengah & 14 & 41,2 & 45 & 44,1 & 59 & 85,3 \\
\hline c. Pendidikan tinggi & 10 & 29,4 & 18 & 17,6 & 28 & 47,1 \\
\hline
\end{tabular}

Tabel 2. Asupan Seng, Status Gizi dan Penyakit Penyerta Berdasarkan Kelompok Kasus dan Kontrol

\begin{tabular}{lcccccc}
\hline \multirow{2}{*}{ Variabel } & \multicolumn{2}{c}{ Kasus } & \multicolumn{2}{c}{ Kontrol } & \multicolumn{2}{c}{ Total } \\
\cline { 2 - 7 } & $\mathrm{n}(34)$ & $\%$ & $\mathrm{n}(102)$ & $\%$ & $\mathrm{n}(136)$ & $\%$ \\
\hline Asupan seng & & & & & & \\
$\quad$ a. Kurang & 16 & 47,1 & 46 & 45,1 & 62 & 45,6 \\
$\quad$ b. Cukup & 18 & 52,9 & 56 & 54,9 & 74 & 54,4 \\
Status gizi & & & & & & \\
$\quad$ a. Gizi kurang & 3 & 8,8 & 7 & 6,9 & 10 & 7,4 \\
$\quad$ b. Gizi baik & 31 & 91,2 & 95 & 93,1 & 126 & 92,7 \\
Penyakit penyerta & & & & & & \\
$\quad$ a. Ada & 11 & 32,4 & 12 & 11,8 & 23 & 16,9 \\
$\quad$ b. Tidak ada & 23 & 67,7 & 90 & 88,2 & 113 & 83,1 \\
\hline Keterangan. $n=$ Jumanyyyyyyyyyyyyy
\end{tabular}


Tabel 3. Analisis Uji Mantel-Haenszel antara Asupan Seng dan Pneumonia

\begin{tabular}{|c|c|c|c|c|c|c|c|c|}
\hline \multirow{3}{*}{$\begin{array}{l}\text { Kasus } \\
\text { Asupan seng }\end{array}$} & \multirow{2}{*}{\multicolumn{4}{|c|}{$\begin{array}{c}\text { Kontrol } \\
\text { Asupan Seng }\end{array}$}} & \multirow[t]{3}{*}{ OR } & \multirow[t]{3}{*}{$\mathrm{Cl}(95 \%)$} & \multirow{3}{*}{$\chi^{2}$} & \multirow[t]{3}{*}{$p$} \\
\hline & & & & & & & & \\
\hline & 0 & 1 & 2 & 3 & & & & \\
\hline Kurang & 4 & 5 & 6 & 1 & 1,08 & $0,5-2,3$ & 0,00 & 1 \\
\hline Cukup & 2 & 7 & 8 & 1 & & & & \\
\hline
\end{tabular}

Tabel 4. Hasil Analisis Uji Mantel-Haenszel antara Status Gizi dan Penyakit Penyerta Berdasarkan Pneumonia

\begin{tabular}{|c|c|c|c|c|c|c|c|c|}
\hline \multirow{3}{*}{ Kasus } & \multicolumn{4}{|c|}{ Kontrol } & \multirow{3}{*}{ OR } & \multirow{3}{*}{$\mathrm{Cl}(95 \%)$} & \multirow{3}{*}{$\chi^{2}$} & \multirow[b]{3}{*}{$p$} \\
\hline & \multicolumn{4}{|c|}{ Status Gizi } & & & & \\
\hline & 0 & 1 & 2 & 3 & & & & \\
\hline \multicolumn{9}{|l|}{ Status gizi } \\
\hline Gizi kurang & 2 & 1 & 0 & 0 & \multirow[t]{2}{*}{0,3} & \multirow[t]{2}{*}{$0,6-1,6$} & \multirow[t]{2}{*}{2} & \multirow[t]{2}{*}{0,1} \\
\hline Gizi baik & 25 & 6 & 0 & 0 & & & & \\
\hline \multirow{3}{*}{ Kasus } & \multicolumn{4}{|c|}{ Kontrol } & \multirow{3}{*}{ OR } & \multirow{3}{*}{$\mathrm{Cl}(95 \%)$} & \multirow{3}{*}{$\chi^{2}$} & \multirow{3}{*}{$p$} \\
\hline & & akit & ye & & & & & \\
\hline & 0 & 1 & 2 & 3 & & & & \\
\hline \multicolumn{9}{|l|}{ Penyakit penyerta } \\
\hline Ada & 8 & 3 & 0 & 0 & 2,1 & $0,76-5,8$ & 2,1 & 0,1 \\
\hline Tidak ada & 17 & 3 & 3 & 0 & & & & \\
\hline
\end{tabular}

Tabel 5. Analisis Conditional Logistic Regression antara Asupan Seng, Status Gizi, dan Penyakit Penyerta terhadap Pneumonia

\begin{tabular}{|c|c|c|c|c|}
\hline Variabel & $\begin{array}{c}\text { Model } 1 \\
\text { OR } \\
(\mathrm{Cl} 95 \%)\end{array}$ & $\begin{array}{c}\text { Model } 2 \\
\text { OR } \\
\text { (Cl 95\%) }\end{array}$ & $\begin{array}{c}\text { Model } 3 \\
\text { OR } \\
\text { (Cl 95\%) }\end{array}$ & $\begin{array}{c}\text { Model } 4 \\
\text { OR } \\
(\mathrm{Cl} 95 \%)\end{array}$ \\
\hline \multicolumn{5}{|l|}{ 1. Asupan seng } \\
\hline a. Kurang & $\begin{array}{c}1,07 \\
0,5-2,3\end{array}$ & $\begin{array}{c}1,04 \\
0,4-2,2\end{array}$ & $\begin{array}{c}1,06 \\
0,4-2,3\end{array}$ & $\begin{array}{c}0,9 \\
0,4-2,2\end{array}$ \\
\hline b. Cukup & 1 & 1 & 1 & 1 \\
\hline \multicolumn{5}{|l|}{ 2. Status gizi } \\
\hline a. Gizi Kurang & & $\begin{array}{c}1,2 \\
0,2-5,5\end{array}$ & & $\begin{array}{c}2,1 \\
0,4-11,4\end{array}$ \\
\hline b. Gizi Baik & & 1 & & 1 \\
\hline \multicolumn{5}{|l|}{ 3. Penyakit penyerta } \\
\hline a. Ada & & & $\begin{array}{c}3,8^{*} \\
1,4-10,8\end{array}$ & $\begin{array}{c}4,3^{*} \\
1,5-12,6\end{array}$ \\
\hline b. Tidak ada & & & 1 & 1 \\
\hline-2 loglikehood & $-47,1$ & $-47,1$ & $-43,5$ & $-43,1$ \\
\hline Deviance & 94,2 & 94,1 & 87,1 & 86,2 \\
\hline $\mathrm{R}^{2}$ & 0,0 & 0,0 & 0,07 & 0,08 \\
\hline
\end{tabular}


Dari 136 sampel penelitian, diketahui 23 $(16,9 \%)$ anak memiliki penyakit penyerta, yang terdiri dari 11 (32,4\%) anak pada kelompok kasus dan $12(11,8 \%)$ anak pada kelompok kontrol. Tabel 3 menggambarkan besar risiko asupan seng terhadap pneumonia.

Asupan seng yang kurang pada kelompok pasangan kasus dan kontrol, terdapat 1 pasangan konkordan dan 2 pasangan konkordan pada kasus dan kontrol untuk asupan gizi cukup. Pasangan diskordan bervariasi: terdapat pada 4 pasang kasus dengan asupan seng kurang dan tidak ada kontrol dengan asupan seng kurang; 5 pasang kasus dengan asupan seng kurang dan 1 kontrol dengan asupan seng kurang; 7 pasang kasus pada asupan seng cukup dan 1 kontrol asupan seng kurang. Terdapat 6 pasang kasus asupan seng kurang dan 2 kontrol asupan seng kurang, 8 pasang kasus asupan seng cukup dengan 2 kontrol kasus asupan seng kurang, dan terdapat 1 pasang asupan seng cukup dengan 3 kontrol asupan seng kurang. Hasil analisis menunjukkan, nilai $p>0,05 ;$ OR 1,08 dengan $\mathrm{Cl} 95 \%$ 0,5-2,3. Tidak ada hubungan antara asupan seng dan pneumonia.

Tabel 4 menunjukkan bahwa tidak terdapat pasangan konkordan status gizi kurang dan terdapat 25 pasang konkordan pada status gizi baik. Pasangan diskordan bervariasi: terdapat 2 pasang kasus gizi kurang dan tidak ada kontrol; 1 pasang kasus gizi kurang dengan 1 kontrol gizi kurang; dan 6 pasang kasus gizi baik dengan 1 kontrol gizi kurang. Hasil analisis yang didapatkan adalah nilai $p>0,05$; OR 0,3 dan $\mathrm{Cl}$ $95 \%$ 0,6-1,6. Tidak ada hubungan yang bermakna antara status gizi dan pneumonia.

Hasil perhitungan pada penyakit penyerta menunjukkan, tidak terdapat pasangan konkordan pada pasangan kasus yang ada penyakit penyerta. Terdapat 17 pasang konkordan kasus penyakit penyerta tidak ada. Pasangan diskordannya bervariasi, yaitu 8 pasang kasus ada penyakit penyerta dengan tidak ada kontrol ada penyakit penyerta; 3 pasang kasus ada penyakit penyerta dengan 1 kontrol ada penyakit penyerta; 3 pasang kasus tidak ada penyakit penyerta dan 1 kontrol ada penyakit penyerta; serta 3 pasang kasus tidak ada penyakit penyerta dengan 2 kasus ada penyakit penyerta. Hasil analisis yang didapatkan adalah nilai $p>0,05 ;$ OR 2,1 dan $\mathrm{Cl}$ $95 \%$ 0,7-5,8. Hasil tersebut menunjukkan bahwa penyakit penyerta tidak menunjukkan hubungan bermakna secara statistik, tetapi secara klinis mempunyai hubungan atau ada perbedaan antara kelompok anak dengan keberadaan penyakit penyerta dan anak yang tidak ada penyakit penyerta sehingga berpeluang meningkatkan keparahan pneumonia sebesar 2,1 kali dibandingkan dengan anak yang tidak ada penyakit penyerta.

Tabel 5 menunjukkan hubungan antara asupan seng dan pneumonia serta mengikutsertakan status gizi dan penyakit penyerta. Model 3 dibangun untuk menganalisis hubungan antara asupan seng dan keparahan pneumonia dengan mengontrol penyakit penyerta. Hasil analisis menunjukkan bahwa secara statistik ada hubungan signifikan antara penyakit penyerta dengan keparahan pneumonia. Adanya penyakit penyerta mengubah nilai OR dari 1,06 menjadi $3,8(\mathrm{Cl}$ $95 \%$ 1,4-10,8). Artinya, anak yang menderita pneumonia dan asupan seng yang kurang berpeluang 3,8 kali untuk mendapatkan pneumonia berat jika disertai adanya penyakit penyerta. Nilai OR penyakit penyerta adalah 3,8 (Cl 95\% 1,4-10,8) dan nilai $R^{2}=0,07$. Artinya, asupan seng yang kurang disertai adanya penyakit penyerta dapat memprediksi terjadinya pneumonia berat sebesar 7 persen.

Model 4 dibangun untuk menganalisis hubungan antara asupan seng dan keparahan pneumonia dengan mengikutsertakan status gizi dan penyakit penyerta. Hasil analisis menunjukkan bahwa penyakit penyerta memiliki hubungan yang signifikan secara statistik dan praktis terhadap keparahan pneumonia, dengan nilai OR 4,3 (Cl 95\%=1,5-12,6). Artinya, anak dengan asupan seng kurang, gizi kurang dan disertai adanya penyakit penyerta dapat memberikan peluang terjadinya keparahan pneumonia sebesar 4,3 kali. Nilai $R^{2}=0,08$. Artinya, adanya asupan seng kurang, gizi kurang dan penyakit penyerta dapat memprediksi terjadinya keparahan pneumonia pada anak sebesar 8 persen.

\section{BAHASAN}

\section{Pneumonia}

Pada penelitian ini, anak yang menderita pneumonia berat lebih banyak terjadi pada anak laki-laki dibandingkan anak perempuan Penelitian lain yang dilakukan di Asia Selatan 
(India, Pakistan, dan Bangladesh) menunjukkan bahwa secara substansi perbedaan kerentanan jenis kelamin ini berhubungan dengan pentingnya faktor budaya, seperti preferensi pencarian pelayanan kesehatan untuk anak laki-laki. Beban penyakit secara global cenderung tidak melibatkan jenis kelamin pada kematian anak akibat pneumonia. Oleh karena itu angka kematian yang melibatkan jenis kelamin tersebut tidak jelas. ${ }^{12}$ Anak yang menderita pneumonia berat mempunyai asupan seng yang lebih sedikit pada anak laki-laki dibandingkan anak perempuan sehingga anak laki-laki lebih rentan terhadap pneumonia. ${ }^{13} \mathrm{Hal}$ tersebut menggambarkan preferensi kebudayaan setempat dan gender. Anak lakilaki membutuhkan lebih banyak asupan seng dibandingkan anak perempuan untuk pertumbuhan sehingga asupan zat gizi dan perbedaan imunologi berefek pada infeksi dan kelangsungan hidup..$^{14}$

Hasil penelitian sebelumnya yang dilakukan Walker et al. menunjukkan bahwa 81 persen kematian akibat penumonia terjadi pada anak usia di bawah 2 tahun. ${ }^{15}$ Berbeda dengan hasil penelitian yang dilakukan Shah et al, yang menunjukkan bahwa anak yang berusia 2-35 bulan lebih banyak menderita pneumonia di Nepal. ${ }^{16}$ Hasil penelitian yang dilakukan Pushpa et al. juga menyimpulkan bahwa anak usia 1360 bulan sebesar 70 persen menderita pneumonia dan mengalami kekurangan seng dibandingkan anak usia 2-12 bulan. Kebutuhan seng cukup sejak anak dalam kandungan sampai usia 4 bulan kelahiran, tetapi makin bertambah besar kebutuhan seng anak juga semakin meningkat pada saat menyapih. Maka, pada umumnya anak yang berusia lebih dari 6 bulan di negara berkembang mengalami kesulitan untuk pemenuhan kebutuhan seng tersebut. ${ }^{17}$

Sejumlah 58,8 persen kasus tidak mendapat ASI eksklusif dan secara keseluruhan, kurang dari separuh sampel penelitian mendapatkan ASI eksklusif. Anak yang diberikan ASI eksklusif sampai usia 6 bulan pertama cenderung memiliki gizi cukup sehingga kekebalan tubuh meningkat dan menurunkan risiko penyakit infeksi. Hasil penelitian sebelumnya di India terhadap 70 anak menunjukkan anak usia 12 bulan yang diberi susu formula dan diperiksa secara radiologi cenderung terinfeksi 8 episode pneumonia. ${ }^{18}$ Pemberian ASI eksklusif menurunkan 23 persen kejadian pneumonia dan 15,1 kali lebih berisiko kematian akibat pneumonia jika tidak disusui dalam enam bulan pertama (RR 1,26-2,5). ${ }^{19}$

Komponen tersebut bekerja secara terpisah sampai respon imun berkembang..$^{20}$ ASI eksklusif yang diberikan pada bayi memberikan manfaat imunologi, psikologi, sosial, ekonomi dan lingkungan. Strategi intervensi penyuluhan merekomendasikan bahwa ASI merupakan makanan terbaik bagi bayi baru lahir.

Sebagian besar $(85,3 \%)$ ibu sampel penelitian berpendidikan menengah. Beberapa penelitian menunjukkan bahwa pendidikan rendah pada ibu dan tidak berpengalaman sebagai pengasuh merupakan dua faktor utama ibu tidak mengenal gejala peneumonia anak. Penelitian sebelumnya juga menyimpulkan hasil yang sama bahwa mengenal gejala pneumonia dan status tingkat pendidikan ibu secara statistik bermakna $(p=0,04) \cdot{ }^{21}$ Sama halnya dengan penelitian yang dilakukan Uwaezuoke et al. yang menyimpulkan bahwa skor pengetahuan ibu mengenai tanda dan gejala pneumonia meningkat secara signifikan dengan meningkatnya tingkat pendidikan ibu. Makin tinggi pendidikan ibu, semakin mudah ibu menerima hal-hal baru dan mempermudah penyesuaiannya. ${ }^{22}$ Penelitian yang dilakukan Parvez et al. menunjukkan bahwa pemberian pendidikan kesehatan yang spesifik pada ibu terkait pneumonia dapat memperkecil dan mencegah angka kematian pada anak. ${ }^{23}$

\section{Hubungan asupan seng dengan keparahan pneumonia}

Hasil analisis bivariat (Tabel 3) menunjukkan bahwa asupan seng tidak bermakna secara statistik terhadap keparahan pneumonia. Nilai OR 1,08; artinya, anak dengan asupan seng kurang tidak mempunyai peluang terjadi pneumonia berat. Pada analisis multivariat yang disajikan pada Tabel 5 , yaitu dengan mengikutsertakan penyakit penyerta, menunjukkan adanya hubungan yang bermakna terhadap terjadinya keparahan pneumonia.

Seng aktif pada fase respon aktif terhadap infeksi membantu meningkatkan respon kekebalan tubuh. Caranya adalah dengan memobilisasi jaringan yang kaya methallothonein, meregulasi cepat sistem imun, yaitu sintesis protein khusus dengan 
mengaktifkan sistem imun seperti makrofag, limfosit, sel pembunuh alami dan antibodi sitotoksitas terikat. Anak-anak dengan asupan seng baik memiliki respon imun yang kuat dibandingkan dengan anak dengan asupan seng yang buruk. ${ }^{24}$ Tingkat serum seng berhubungan dengan kondisi kritis pada kasus pneumonia berat. Rendahnya serum seng pada anak penderita pneumonia menandakan anak tersebut membutuhkan bantuan alat pernapasan. ${ }^{13} \mathrm{Hal}$ tersebut terjadi karena tingkat seng rendah pada pneumonia berat merupakan awal dari defisiensi yang membuat anak lebih rentan terhadap pneumonia akibat imunitas yang terganggu. Tingkat seng yang rendah tersebut mempermudah timbulnya infeksi pernapasan sehingga merespon sitokinesis (IL6) yang menyebabkan perpindahan seng dari plasma ke hati sehingga terjadi fase respon akut. ${ }^{17}$

Berbeda dengan penelitian yang dilakukan Coles et al, hasil penelitiannya menunjukkan bahwa secara statistik status seng tidak mempengaruhi terjadinya pneumonia. Dilihat dari hasil analisis, penelitian menunjukkan defisiensi seng atau konsentrasi plasma seng tidak berhubungan dengan terjadinya pneumonia karena prevalensi defisiensi seng relatif rendah pada masyarakat. ${ }^{25}$ Penelitian ini didukung oleh penelitian yang dilakukan Chandyo et al. terhadap anak usia 2-35 bulan penderita pneumonia di Nepal, yang menyimpulkan bahwa pemberian seng tidak menurunkan insiden pneumonia dalam enam bulan berikutnya. ${ }^{26}$ Pemberian seng pada anak pneumonia tidak menurunkan keparahan pneumonia atau lamanya dirawat di rumah sakit pada anak usia 2-35 bulan karena sampel penelitian tidak mengalami defisiensi seng. ${ }^{16}$

\section{Hubungan gizi kurang dengan keparahan pneumonia}

Hasil analisis bivariat (Tabel 4) menunjukkan bahwa secara statistik tidak ada hubungan yang signifikan antara gizi kurang dengan keparahan pneumonia. Analisis multivariat (Tabel 5) menunjukkan, ada hubungan yang bermakna antara status gizi dengan terjadinya keparahan pneumonia. Nilai OR 2,1; artinya, anak dengan gizi kurang mempunyai peluang menderita keparahan penumonia 2,1 kali dibandingkan dengan anak yang memiliki gizi baik.
Penelitian ini didukung oleh penelitian yang dilakukan Pushpa et al. yang menyimpulkan bahwa hubungan antara status gizi dengan tingkat serum seng proporsional antara satu sama lain. Artinya, serum seng yang rendah tidak hanya terdapat pada anak yang menderita gizi kurang, tetapi juga pada anak yang mempunyai gizi baik. ${ }^{17}$

Defisiensi zat gizi mikro juga terjadi pada anak dengan gizi baik. Gizi kurang berkontribusi pada tingginya angka morbiditas pada anakanak, tetapi kontribusi ini tidak berlangsung terus selama penyakit ini terjadi, walaupun bukti menunjukkan bahwa BB/U yang rendah menambah risiko terjadinya pneumonia dan penyakit infeksi lainnya. ${ }^{27}$

Anak yang mengalami gizi kurang berkontribusi pada kematian anak. ${ }^{3}$ Hubungan antara gizi kurang dan terjadinya pneumonia didukung oleh penelitian yang telah dilakukan di Costa Rica, yang menunjukkan bahwa rendahnya $z$-score menurut indeks $\mathrm{BB} / \mathrm{U}$ memiliki risiko untuk terjadinya pneumonia 3,9 kali yang membutuhkan rawat inap. Penelitian di Filipina menunjukkan, anak-anak dengan zscore menurut indeks BB/U antara -2 sampai dengan -3 mempunyai risiko relatif 1,9 kali untuk mendapatkan pneumonia, sedangkan penelitian di Papua Nugini menyebutkan, peluang terjadinya pneumonia 2,1 kali dengan z-score menurut indeks BB/U $<-2 .{ }^{28}$

Kebutuhan asupan seng semakin meningkat pada anak-anak sejalan dengan pertumbuhannya. Pola makan yang baik dengan memaksimalkan keterpaduan KIA-GIZI perlu diberikan pada anak untuk kebutuhan asupan seng dan menghindari penyakit pneumonia. Strategi untuk meningkatkan peran petugas kesehatan perlu ditingkatkan dalam memberikan komunikasi, informasi dan edukasi pada ibu-ibu yang memiliki anak balita, terutama yang menderita pneumonia.

\section{Hubungan penyakit penyerta dan keparahan pneumonia}

Hasil analisis multivariat yang disajikan pada Tabel 5 menunjukkan, adanya hubungan signifikan antara penyakit penyerta dan keparahan pneumonia $(p=0,02) \mathrm{OR}=3,8$ dengan $\mathrm{Cl} 95 \%$ 1,4-10,8. Artinya, adanya penyakit penyerta dapat meningkatkan terjadinya pneumonia berat sebesar 3,8 kali dibandingkan 
dengan anak yang tidak mempunyai penyakit penyerta.

Penelitian sebelumnya yang dilakukan Onyango et al. menyimpulkan bahwa anak yang memiliki penyakit penyerta 4 kali lebih mudah terkena pneumonia berat $(\mathrm{OR}=3,1$ dengan $\mathrm{Cl}$ $95 \%$ 1,2-7,7), karena penyakit penyerta menyebabkan sistem kekebalan tubuh menurun sehingga peka terhadap penyakit yang lebih berat. ${ }^{29}$ Penelitian terbaru mengindikasikan bahwa pneumonia dan diare berkaitan erat dan sering terjadi secara bersamaan pada anakanak. Pneumonia dan diare mempunyai faktor risiko yang sama, seperti kemiskinan, gizi kurang, dan kondisi lingkungan rumah yang buruk sehingga kondisi anak yang pneumonia menjadi lebih buruk dengan adanya diare. Penyakit lain seperti malaria memiliki kecenderungan untuk meningkatkan keparahan pneumonia. ${ }^{10}$

\section{SIMPULAN DAN SARAN}

\section{Simpulan}

Kurangnya asupan seng berpengaruh terhadap terjadinya keparahan pneumonia jika disertai adanya penyakit penyerta anak penderita pneumonia usia 12-59 bulan.

\section{Saran}

Bagi pengelola gizi di Rumah Sakit dan Puskesmas perlu adanya penyuluhan tentang manajemen terpadu tentang perawatan dan pemberian makan tinggi seng bagi anak penderita pneumonia akut atau yang berobat jalan sehingga keterpaduan KIA-GIZI dapat dilaksanakan dengan maksimal.

\section{RUJUKAN}

1. Kementerian Kesehatan, Badan Penelitian dan Pengembangan Kesehatan (Balitbangkes). Pokok-pokok Hasil Riskesdas Indonesia Tahun 2013. Buku 1. Jakarta: Kementerian Kesehatan RI, 2014.

2. Kementerian Kesehatan RI. Pusat Data dan Surveilans Epidemiologi. Pneumonia Balita: Situasi Pneumonia Balita di
Indonesia. Buletin Jendela Epidemiologi, September 2010, 3:1-10.

3. World Health Organization. Integrated Approaches to Prevent and Manage Pneumonia and Diarrhoea for Achievement of MDG 4. Report of South-East Asia Regional Workshop, Dhaka, 27-30 September 2011, 2012.

4. Shakur MS, Malek MA, Bano N, Islam K. Zinc status in well nourished Bangladeshi children suffering from acute lower respiratory infection. Indian Pediatr. 2004; 41(5): 478-81.

5 Mulholland K. Childhood pneumonia mortality: a permanent global emergency. Lancet 2007; 370(9583): 285-9.

6. UNICEF. Strategy to Reduce Maternal and Child Undernutrition. East Asia \& Pacific Regional Office Health and Nutrition Working Paper. Bangkok: UNICEF East Asia and Pacific Regional Office, 2003.

7. Schuchat A; Dowell SF. Pneumonia in children in the developing world: new challenges, new solutions. Semin Pediatr Infect Dis 2004,15(3):181-9.

8. Supariasa IDN, Bakri B, Fajar I. Penilaian Status Gizi. Jakarta: EGC, 2012.

9. Bhutta ZA, Das JK, Walker N, Rizvi A, Campbell H, Rudan I, et al. Interventions to address deaths from childhood pneumonia and diarrhoea equitably: what works and at what cost?. Lancet 2013; 381(9875): 141729.

10. Gupta GR. Tackling pneumonia and diarrhoea: The deadliest diseases for the world's poorest children. Lancet 2012; 379(9832): 2123-4.

11. Cervantes-Rios E, Ortiz-Muñiz R, MartinezHernández AL, Cabrera-Rojo L, GranielGuerrero J, Rodriguez-Cruz L. Malnutrition and infection influence the peripheral blood reticulocyte micronuclei frequency in children. Mutat Res. 2012; 731(1-2): 68-74. 
12. Nair $H$, Simões EA, Rudan I, Gessner BD, Azziz-Baumgartner $\mathrm{E}$, Zhang JS, et al. Global and regional burden of hospital admissions for severe acute lower respiratory infections in young children in 2010: a systematic analysis. Lancet 2013; 381(9875): 1380-90.

13. Rady HI, Rabie WA, Rasslan HA, El Ayadi AA. Blood zinc levels in children hospitalized with pneumonia: a cross sectional study. Egyptian Journal of Chest Diseases and Tuberculosis 2013; 62(4): 697-700.

14. Sazawal S, Black RE, Ramsan M, Chwaya HM, Dutta A, Dhingra U, et al. Effect of zinc supplementation on mortality in children aged 1-48 months: a community-based randomised placebo-controlled trial. Lancet 2007; 369(9565): 927-34.

15. Walker $\mathrm{CL}$, Rudan I, Liu L, Nair $\mathrm{H}$, Theodoratou E, Bhutta ZA, et al. Global burden of childhood pneumonia and diarrhoea. Lancet 2013; 381(9875): 140516.

16. Shah GS, Dutta AK, Shah D, Mishra OP. Role of zinc in severe pneumonia: a randomized double bind placebo controlled study. Ital J Pediatr 2012; 38: 36. doi: 10.1186/1824-7288-38-36.

17. Pushpa, Lohano M, Memon M. Association of serum zinc level with severe pneumonia in children. Pak J Nutr 2009, 8(12): 1873-6.

18. Singh V. The burden of pneumonia in children: an Asian perspective. Paediatr Respir Rev 2005, 6(2): 88-93.

19. WHO dan UNICEF. Ending Preventable Child and Deaths from Pneumonia and Diarrhoea by 2025: The Integrated Global Action Plan for Pneumonia and Diarrhoea (GAPPD). Geneva: WHO, 2013.

20. Walker A. Breast milk as the gold standard for protective nutrients. J Pediatr 2010; 156(2 Suppl): S3-7.

21. Memon KN, Shaikh K, Pandhiani BS, Usman G. How do mothers recognize \& treat pneumonia in their children at home?
A study in Union Council Jhudo, District Mirpurkhas. J Liaquat Uni Med Health Sci 2013; 12(3): 208-13.

22. Uwaezuoke SN, Emodi IJ, Ibe BC. Maternal perception of pneumonia in children: a health facility survey in Enugu, eastern Nigeria. Ann Trop Paediatr 2002; 22(3): 281-5.

23. Parvez MM, Wiroonpanich W, Naphapunsakul M. The effects of educational program on child care knowledge and behaviors of mothers of children under five years with pneumonia. Bangladesh J Med Sci 2010; 9(3): 136-41.

24. Brooks WA, Yunus $M$, Santosham $M$, Wahed MA, Nahar K, Yeasmin S, et al. Zinc for severe pneumonia in very young children: double-blind placebo-controlled trial. Lancet 2004; 363(9422): 1683-8.

25. Coles CL, Fraser D, Givon-Lavi N, Greenberg D, Gorodischer R, Bar-Ziv J, et al. Nutritional status and diarrheal illness as independent risk factors for alveolar pneumonia. Am J Epidemiol. 2005; 162(10): 999-1007.

26. Chandyo RK, Shrestha PS, ValentinerBranth P, Mathisen M, Basnet S, Ulak M, et al. Two weeks of zinc administration to Nepalese children with pneumonia does not reduce the incidence of pneumonia or diarrhea during the next six months. J Nutr 2010; 140(9): 1677-82.

27. Caulfield LE, de Onis M, Blössner M, Black $\mathrm{RE}$. Undernutrition as an underlying cause of child deaths associated with diarrhea, pneumonia, malaria, and measles. Am J Clin Nutr 2004; 80(1): 193-8.

28. Victora CG, Kirkwood BR, Ashworth A, Black RE, Rogers S, Sazawal S, et al. Potential interventions for the prevention of childhood pneumonia in developing countries: improving nutrition. Am J Clin Nutr 1999, 70(3): 309-20.

29. Onyango D, Kikuvi G, Amukoye E, Omolo $J$. Risk factors of severe pneumonia among children aged 2-59 months in western 
Kenya: a case control study. Pan Afr Med J

2012; 13: 45. 